\title{
Transition to Parenthood and Susceptibility to Divorce: qualitative research of divorced young parents in Slovenia
}

\begin{abstract}
Transition to parenthood is a vulnerable period for spouses and can consequently lead to the disintegration of their relationship. The purpose of this research was to examine the experience of this transition, circumstances and risk factors for divorce from the perspective of divorcees in Slovenia who divorced in the first year of their child's life. On the basis of semi-structured interviews with 15 divorcees, the findings of studies examining changes after the birth of a child were confirmed. The results pointed to risk factors for marriage, such as uncertain relationship between spouses prior to the childbirth, permeable boundaries in relations with families of origin, lack of practical and emotional support, and unreal expectations. The child's arrival accentuates unsolved issues from the past and brings additional vulnerability to the relationship. The findings of this research are a contribution to the development of preventive, educative and therapeutic programmes for couples in transition to parenthood.
\end{abstract}

\section{Keywords}

Transition to parenthood, changes at the birth of a child, disintegration of marriage, divorce, risk factors.

\section{Introduction}

For spouses, the birth of the first child is one of the most significant events in their lives, which can profoundly interfere with their mutual relationship while 
they adapt to changes brought on by life in a family of three. At the beginning of the research of this phenomenon, transition to parenthood, i.e. time period which authors define as the period of some months before the birth of a child to, in most cases, the end of a child's first year, was understood exclusively as a crisis for marital relationship. ${ }^{1}$ Later, the term "crisis stage" softened into a "stressful" time period when crisis is not necessarily present ${ }^{2}$. Today, transition to parenthood is generally defined as a period of vulnerability for marriage ${ }^{3}$ which contributes to the development of a relationship in various possible directions.

Studies ${ }^{4}$ show that in the formation period of a new family, the so-called family of procreation, stress increases; new responsibilities and the need to adapt open new emotional contents, increasing sensitivity in marital relationship. In connection with changes spouses experience, most frequently mentioned areas are marital quality and marital satisfaction, division of labour and child care, relations within wider and closer social network, identity, habits, values, and sexual life ${ }^{5}$ and these changes can swing a relationship to the point where dissolution of a marriage is inevitable.

The divorce rate of young children's parents is difficult to establish. According to available statistics in Slovenia, a central European country, the number of

${ }^{1}$ E. E. LeMasters, Parenthood as crisis, "Marriage and family living" 19 (1957), p. 352-355.

2 A. Rossi, Transition to parenthood, "Journal of Marriage and the Family" 30 (1968), p. 26-29.

${ }^{3}$ D. M. Mitnick, R. E. Heyman, A. M. Smith Slep, Changes in relationship satisfaction across the transition to parenthood: A meta-analysis, "Journal of Family Psychology" 23 (2009) 6, p. 848-852; N. Rijavec Klobučar, The role of spirituality in transition to parenthood: qualitative research using transformative learning theory, "Journal of Religion and Health" 54 (2015) (in press).

${ }^{4}$ P. A. Cowan, C. P. Cowan, When partners become parents: The big life change for couples, New York 1992, Basic Books; B. D. Doss, G. K. Rhoades, S. M. Stanley, H. J. Markman, The effect of the transition to parenthood on relationship quality: An eight-year prospective study, "Journal of Personality and Social Psychology" 96 (2009) 3, p. 601-619.

${ }^{5}$ See J. Belsky, The transition to parenthood. How a first child changes marriage, New York 1994, Delacorte Press; P. A. Cowan, C. P. Cowan, When partners become parents: The big life change for couples, New York 1992, Basic Books; D. M. Mitnick, R. E., Heyman, A. M. Smith Slep, Changes in relationship satisfaction across the transition to parenthood: A meta-analysis, "Journal of Family Psychology” 23 (2009) 6, p. 848-852; J. M. Gottman, A. F. Shapiro, J. Parthemer, Bringing the baby home: A workshop for new and expectant parents, "International Journal of Childbirth Education" 19 (2004) 3, p. 28-30. 
weddings is decreasing; in 2013 , even $58 \%$ children were born in non-marital relationships ${ }^{6}$ and disintegrations of these relationships are not included in statistics. Data from 2014 do show that the share of those who at the time of divorce do not have dependent children (i.e. underage children and children up to 26 years of age who still attend universities) and the share of those with children (50,1\%) almost levelled (49,9\% without children, 50,1\% with children). From these data it is not possible to conclude how many relationships dissolved during transition to parenthood, what life situations, problems and adversities spouses face during transition to parenthood, and what changes they have to cope with. Further on, we will shed light on some of these areas so as to better understand their relation to divorce.

\section{Marital quality and marital satisfaction before and after the birth of a child}

One of the most frequently studied dimensions of marital relationship after the birth of a child is marital quality, which encompasses marital adaptation and marital satisfaction ${ }^{7}$. Findings are not unanimous about whether a child influences changes in the quality of a relationship. Some findings ascribe to the birth of a child negative effects on the marriage ${ }^{8}$ others argue that between parents and non-parents there are no differences in the decrease of marital satisfaction; this decrease can also be perceived in non-parents because it is

${ }^{6}$ Eurostat, Marriage and divorce statistics, http://ec.europa.eu/eurostat/statisticsexplained/ index.php/Marriage_and_divorce_statistics (15.07.2015).

${ }^{7}$ B. D. Doss, G. K. Rhoades, S. M. Stanley, H. J. Markman, The effect of the transition to parenthood on relationship quality: An eight-year prospective study, "Journal of Personality and Social Psychology" 96 (2009) 3, p. 601-619; W. K. Halford, J. Petch, D. Creedy, Promoting a positive transition to parenthood: A randomized clinical trial of couple relationship education, "Prevention Science" 11 (2009) 1, p. 89-100.

${ }^{8}$ B. D. Doss, G. K. Rhoades, S. M. Stanley, H. J. Markman, The effect of the transition to parenthood on relationship quality: An eight-year prospective study, "Journal of Personality and Social Psychology" 96 (2009). 3, p. 601-619; W. K. Halford, J. Petch, D. Creedy, Promoting a positive transition to parenthood: A randomized clinical trial of couple relationship education, "Prevention Science" 11 (2009) 1, p. 89-100. 
something that happens with time ${ }^{9}$ however, a recent meta-analysis ${ }^{10}$ revealed that parents in this period of time are less satisfied than non-parents.

With regards to the questions of adequacy of research methodology used and the eligibility of the comparison of couples with children to those without children, in longitudinal monitoring of couples it has been noted that the change in the quality of relationship after the birth of a child depends on marital quality before the birth. Marital quality is intertwined with other risk factors for the dissolution of marriage, where scholars ${ }^{11}$; include younger age at the time of marriage, lower socioeconomic status, absence of religious affiliation, cohabitation, pregnancy prior to marriage, long duration of marriage, and the experience of spouses' parents' divorce.

Early marital dissatisfaction potentially leads to divorce ${ }^{12}$ not, however, due to an acute relationship problem at a certain point in time, but because of cumulative, long-term relationship burdens. This accumulation of stress, such as the first three months of life with a newborn are difficult to tolerate. The level of marital satisfaction is intertwined with the motives underlying the decision to have a child. When these motives stem out of dissatisfaction, estrangement and/ or hope that the child's arrival in the lives of unsatisfied spouses will enliven or even solve their marriage, the disappointment felt when this does not happen is all the greater. It is also established that unwanted pregnancy, in comparison with planned and desired pregnancy, is related to greater relationship difficulties, and increases the probability for the marriage to disintegrate ${ }^{13}$.

Therefore, the quality of the relationship between spouses before the birth of a child predicts how they will cope with changes after the birth. When partnership is built on "firm foundations", which means that satisfying levels

9 J. Belsky, The transition to parenthood. How a first child changes marriage, New York 1994, Delacorte Press.

${ }^{10}$ J. M. Twenge, W. K. Campbell, C. A. Foster, Parenthood and marital satisfaction: A metaanalytic review, "Journal of Marriage and Family" 65 (2003) 3, p. 574-583.

${ }^{11}$ P. Amato, Research on divorce: Continuing trends and new developments, "Journal of Marriage and Family” 72 (2000) 3, p. 650-666; B. Simonič, A. Poljanec, Building motherhood in the young mothers' group, "Child Care in Practice" 20 (2014) 3, p. 270-285.

${ }^{12}$ G. Hirschberger, S. Srivastava, P. Marsh, C. P. Cowan, P. A. Cowan, Attachment, marital satisfaction, and divorce during the first fifteen years of parenthood, "Personal Relationships" 16 (2009), p. 401-420.

${ }^{13}$ K. B. Guzzo, S. R. Hayford, Unintended fertility and the stability of coresidential relationships, "Social Science Research" 41 (2012) 5, p. 1138-1151. 
of security, stability, intimacy and commitment are reached, and partners are generally satisfied with their relationship, there is less probability that the relationship after the birth of a child will experience a crisis; they will probably experience the period of transition as a pleasant one. The quality of the marital relationship before the birth of a child is therefore closely related to marital quality after the birth and impacts all other sub-systems in the family ${ }^{14}$. Interpersonal relationship before the birth of a child also predicts the level of parental commitment after the birth.

\section{Division of labour and women's workload}

Transition to parenthood is a time period when patterns are redistributed according to traditional distribution of workload. Women carry out the majority of household workload even where patterns before the birth of a child are equally established. They often complain that their husbands do not participate enough, even when a husband contributes a lot and actively tries to lessen the wife's workload ${ }^{15}$. A woman compares her husband's diligence at household chores with her own, while a man compares his contribution with other fathers and also his own father ${ }^{16}$. On the other hand, men want to contribute more but sometimes they just do not know how. The differences between genders stem from different patterns, habits and beliefs, but marital quality seems to be of the utmost importance.

${ }^{14}$ N. Rijavec Klobučar, Transformativno učenje v partnerskih odnosih na prehodu $v$ starševstvo [Transformative learning in the transition to parenthood], "Andragoška spoznanja” 17 (2011) 3, p. 31-39.

${ }^{15}$ S. N. Biehle, K. D. Mickelson, First-time parents' expectations about the division of childcare and play, "Journal of Family Psychology" 26 (2012) 1, p. 36-45; C. T. Gager, B. Hohmann-Marriott, Distributive justice in the household: A comparison of alternative theoretical models, "Marriage and Family Review" 40 (2006) 2-3, p. 5-42; J. E. Yavorsky, C. M. Kamp Dush, S. J. Schoppe-Sullivan, The production of inequality: The gender division of labor across the transition to parenthood, "Journal of Marriage and Family" 77 (2015) 3, p. 662-679.

${ }^{16} \mathrm{~J}$. Belsky, The transition to parenthood. How a first child changes marriage, New York 1994, Delacorte Press; C. T. Gager, B. Hohmann-Marriott, Distributive justice in the household: A comparison of alternative theoretical models, "Marriage and Family Review" 40 (2006) 2-3, p. 5-42. 
Women's expectations regarding men's active role in carrying out domestic chores are often based on men's engagement with the preparations during pregnancy; that is why women's disappointment and dissatisfaction are much greater when men do not cooperate enough, than when a woman expects that she will have to do everything by herself but this does not happen ${ }^{17}$. Disappointment is not so much a result of unequal division of labour; rather, it stems from dissatisfaction with unrealized expectations, especially when male partners do not share these expectations during pregnancy.

Imbalanced division of labour is a source of conflicts as much as lack of sleep, fatigue and consequent intolerance and irritability. Frequently, under the load of everyday household chores, deeply buried emotions emerge, originating in the time before the birth of a child and in deeper psychological complications from their respective childhoods onwards.

The majority of parents-to-be expect emotional as well as physical support, and this expectation is rarely met where spouses have experienced a lot of negative emotions, adversities and conflicts in their relationship even before the birth of a child ${ }^{18}$.

\subsection{Unrealized expectations and risk of a relationship disintegration}

During pregnancy partners form different expectations about the life with the child, however, what they actually experience often differs from their idealistic vision of a child as the one who only brings positive feelings and strengthens the connection between spouses ${ }^{19}$.

It is established that realistic expectations contribute to smoother transition. Mothers with the so-called optimist attitude who expect feelings of happiness, satisfaction, excitement as well as changes such as lack of sleep, caring for the baby, and lack of time, more easily adapt to motherhood than mothers with so-called pessimist expectations or those with so-called idealist expectations. The

${ }^{17}$ S. N. Biehle, K. D. Mickelson, First-time parents' expectations about the division of childcare and play, "Journal of Family Psychology" 26 (2012) 1, p. 36-45.

${ }^{18}$ B. D. Doss, G. K. Rhoades, S. M. Stanley, H. J. Markman, The effect of the transition to parenthood on relationship quality: An eight-year prospective study, "Journal of Personality and Social Psychology" 96 (2009) 3, p. 601-619.

${ }^{19} \mathrm{~J}$. Belsky, The transition to parenthood. How a first child changes marriage, New York 1994, Delacorte Press; S. N. Biehle, K. D. Mickelson, First-time parents' expectations about the division of childcare and play, "Journal of Family Psychology" 26 (2012) 1, p. 36-45. 
discrepancy between expectations and the real experience makes the transition more difficult in marital relationship, too ${ }^{20}$. Many spouses expect that with the birth of a child their relationship will change, but they do not define what is supposed to change some expect that the relationship will remain the same or that it will, by itself, change for the better. Sometimes spouses are not aware of their mutual differences, which after the birth of a child become more prominent and also disturbing. Sometimes they nurture extremely positive or extremely negative images of their relationship after the birth of a child, and their unsaid and even subconscious expectations, which are often only part of their own visions, have destructive consequences also due to deficient skills and knowledge of interpersonal relationships.

The divorce of parents with very young children is related to spouses' unpreparedness and ignorance how to cope with changes when learning the new parents' role in the first months of living with a child. Individuals with poor conflict-resolution skills before the birth of a child, report increased levels of problems after the birth ${ }^{21}$.

\subsection{Relationships with parents and in-laws}

After the birth of a child, relationships with families of origin are known to bring on one hand additional encouragement and support or, on the other hand, additional burden and stress. If young parents experience the support of their social network, they will undergo the period of vulnerability more easily. Social network of either emotional or practical help is mirrored by positive results and absence of negative consequences. Relationships with parents are also linked to experiences in the family of origin and to the memories of these experiences ${ }^{22}$.

${ }^{20}$ N. Biehle, K. D. Mickelson, First-time parents' expectations about the division of childcare and play, "Journal of Family Psychology" 26 (2012) 1, p. 36-45; K. Harwood, N. McLean, K. Durkin, First-time mothers 'expectations of parenthood: What happens when optimistic expectations are not matched by later experiences, "Developmental Psychology" 43 (2007) 1, p. 1-12.

21 A. F. Shapiro, J. M. Gottman, S. Carrère, The baby and the marriage: identifying factors that buffer against decline in marital satisfaction after the first baby arrives, "Journal of Family Psychology" 14 (2000) 4, p. 59-70.

${ }^{22}$ A. C. Glade, A. R. Bean, R. Vira, A prime time for marital/relational intervention: A review of the transition to parenthood literature with treatment recommendations, "The American Journal of Family Therapy" 33 (2005) 4, p. 319-336. 
Various authors ${ }^{23}$ agree that early relationships within a family are a significant indicator of development of a new family. Relationships with parents which marked an individual's growing up act as indicators for the development of partners' relationships. Parents' divorce impacts adult relationships ${ }^{24}$ by watching parents, children learn how to connect in relationships, how to solve problems and forge interpersonal relationships which they enter with different expectations about intimate relationships than children whose parents have not divorced.

The arrival of a child in a larger family system is an opportunity to refresh relations between several generations and to establish different connections with one's parents. Changes can show in increased closeness or increased distance between two generations of adults. Conflicts in relationships with the family of origin present a potential for change, however, it depends on the young couple if they can establish sufficiently clear and permeable boundaries in a responsible and respectable way, so that grandparents will be included, not excluded), or a high level of conflicts with parents will lead to increasing mutual dissatisfaction and eventual divorce ${ }^{25}$.

Due to all factors mentioned above, our research focused on changes which individuals faced in the period of transition to parenthood, their experiencing and seeing risk factors from their points of view.

\section{Method}

The purpose of the research is to find out what changes are faced by adults, who later divorce, during transition to parenthood; how they perceive circumstances which led to divorce; how they experience and relate to the period of transition

${ }^{23}$ See P. A. Cowan, C. P. Cowan, When partners become parents: The big life change for couples, New York 1992, Basic Books.

${ }^{24} \mathrm{~J}$. Wallerstein, J. Lewis, The unexpected legacy of divorce: Report of a 25-year study, "Psychoanalytic Psychology" 21 (2004) 3, p. 353-370.

${ }^{25} \mathrm{~J}$. Belsky, The transition to parenthood: How a first child changes marriage, New York 1994, Delacorte Press; P. A. Cowan, C. P. Cowan, When partners become parents: The big life change for couples, New York 1992, Basic Books; N. Rijavec Klobučar, Transformativno učenje $v$ partnerskih odnosih na prehodu $v$ starševstvo [Transformative learning in the transition to parenthood], "Andragoška spoznanja" 17 (2011) 3, p. 31-39. 
from the perspective of increased susceptibility to the dissolution of their relationship.

\subsection{Participants}

The research is based on semi-structured interviews with 15 adults ( 9 women and 6 men) who divorced soon after the birth of their first child. Participants decided to divorce in the first year of their child's life, with the formal process concluded by the child's fourth year. At the time of the interviews, no more than 11 years passed from divorce. For all participants, this was their first child.

Participants were 26 to 45 years old; eight of them were in new relationships, seven were single. Four had a child with the new partner. Participants came from all parts of Slovenia. Eleven were financially independent (employed), four were unemployed. At the time of the interviews, three female participants shared households with their parents. Seven women had full custody of the child, one of them shared custody with the child's father, one did not have custody, and the five fathers in the research did not have custody.

\subsection{Procedure}

We conducted semi-structured interviews with participants whom we invited through forums, the mailing list of participants who used to attend a pre-birth programme, and social network. Interviews took 30 to 60 minutes and were conducted at the Family Centre. Prior to interviews, participants were informed, orally and in writing, about the purpose and form of interviewing, as well as of the course of research in accordance with ethical rules. By signing written permits they allowed audio recording of the interviews, which were coded due to anonymity and destroyed after the analysis. The participation was voluntary.

The study was approved by the National Medical Ethics Committee in Ljubljana, Slovenia.

When conducting the interviews, our initial questions were:

- How would you describe the relationship with your spouse before and after the birth of your child?

- Did the relationship change with your baby's birth? How and in which direction? 
- Did the presence of your child influence your decision to divorce? How?

- In retrospective, how do you assess/perceive the factors which contributed to the dissolution of your marriage?

The participants expressed the need for understanding and being heard, so we listened to their life stories without interrupting or commenting; we explained that for the research purpose, their subjective perception and experience are important. Through telling their stories, adults also learn ${ }^{26}$.

\subsection{Analysis}

We processed acquired data according to the principles of a qualitative research method called content analysis. Recorded interviews were transcribed. They were independently analysed by both researchers, who read the text with necessary sensitivity, not mechanically, divided it to code units and independently attributed concepts to these units (coding). During this process, the authors followed research questions. During initial coding the authors mutually discussed problems, dilemmas, and open issues.

Further on, the researchers compared coded texts, chunking those with the same code, and coordinated coding with the rest. Furthermore, related, similar codes with related meanings were chunked in wider categories which bear the meaning of all chunked codes. The researchers were led by the following questions: Can I relate certain codes together under a more general code? Can I organise codes sequentially (for example does code A happen before code B)? Can I identify any causal relationships (does code A cause code B)? ${ }^{27}$ This was followed by analysing of categories, i.e. identifying their characteristics, interrelations, and peculiarities. At the end of data processing, the authors critically reflected on their own role within the whole data collection process, and demonstrated awareness of this, and how it may have influenced findings, to the reader. They also combined the analysis with findings from different data sources.

${ }^{26}$ See also N. Rijavec Klobučar, Transformativno učenje v partnerskih odnosih na prehodu $v$ starševstvo [Transformative learning in the transition to parenthood], "Andragoška spoznanja" 17 (2011) 3, p. 31-39.

${ }_{27}$ M. B. Miles, A. M. Huberman, J. Saldana, Qualitative data analysis: A methods sourcebook, CA 2014, Thousand Oaks, Sage. 


\subsection{Findings}

The research showed the following categories, related to changes after the birth of a child as far as susceptibility to disintegration of marriage is concerned.

\section{Loneliness and fatigue in the first months}

Results show that participants experienced both positive and negative changes after the childbirth. Positive feelings of satisfaction, happiness and joy because of the new baby were intertwined with unpleasant feelings of fatigue and lack of time as well as negative emotions toward the spouse because of disagreements, misunderstanding, and absence.

The majority of female participants described the first three months as an extremely demanding time period; more than exhaustion due to sleepless nights and caring for babies, they were affected by loneliness because of their spouses' non-cooperation. They felt that the husbands did not develop their fatherly roles.

"Not once did he go shopping or to the doctor; I had to call my mother to accompany me. He was of no help. None, none at all. As if I had two kids".

"I was alone; he worked whole days, came home and fell asleep. As if he was my roommate".

"Exhausted to death, disease after disease, and no help from him. I even took a taxi to maternity hospital, while he played games on his tablet. And later he was not with us, either".

"To him it was logical that I get up all the time, that it is my responsibility, while he didn't participate even on weekends. One feels cheated; I felt as if I actually got two kids".

"He didn't take any responsibility; he didn't help with household chores or with taking care of the baby. I had to do everything and I was desperate. I felt the injustice because I was the one to do all the work. I was afraid I wouldn't be able to make it".

The same as in other studies ${ }^{28}$ women in our research took over the majority of household chores and their workload became heavier even in comparison to the time before the childbirth. Dissatisfaction was especially apparent in

${ }^{28}$ J. Belsky, The transition to parenthood. How a first child changes marriage, New York 1994, Delacorte Press; N. Biehle, K. D. Mickelson, First-time parents' expectations about the division of childcare and play, "Journal of Family Psychology" 26 (2012) 1, p. 36-45. 
cases where a woman got no help (e.g. from her mother) nor her spouse's understanding.

"You can barely breathe, the flat is a mess, mother only comes to search for faults, to look for cobwebs; he doesn't touch a thing except beer and remote control".

"You are alone, nobody is there to help you, to take the baby for half an hour so that you can take a shower. And he is at the football match with his friends".

The research confirmed that experiencing difficult moments is related to marital relationship as well as with practical help from parents and unmet biological needs. The women experienced fatigue because of heavy workload and simultaneous husbands' non-cooperation. In case parental help was available they were less exhausted; however, this proved to be only a short-term solution.

The connection of a new mother with her mother or mother-in-law formed a triangle which helped them to make it more easily during first months, since they felt less burdened and tired due to workload and domestic chores; with time, however, male absence started to irritate them.

"To be honest, my mother-in-law did help me, she cooked; but he should have done something. He was husband and father. Not a phantom".

"That he wasn't there, wasn't even there - that was the main reason why we went separate ways. You tolerate it before the child; but with a baby, he should have been there. But he wasn't there, either physically or psychologically".

The women's demand for mutual cooperation remained unheard; they strived to be good mothers but they also wanted to have at their sides a partner and child's father.

\section{A child brings up problems from the past}

After the childbirth, problems emerged which the participants had perceived already in the time before pregnancy. One father in the research said, "It made me sad that I had no support even when we were building our home; she didn't care for the home, she was tired and passive. We didn't even eat at home; she only warmed up dishes her mother had cooked. We rarely went to sleep together in the bedroom. Usually she spent nights in front of TV. Each day I felt deeper regret that I had chosen her as the mother of my children. After the childbirth she became a different person and we became totally estranged".

Mothers, too, noticed problems and troubles, and felt dissatisfied in their marriages; however, they hoped the child would change the husband, regardless 
if the pregnancy had been planned or not. They expected an improvement in their relationships because of their husband's age ("He is old enough to become adult"), because of how their husband treated other children "He loves children, so his own child will touch his heart/made him more serious"), or with the fact that at the beginning of their relationship, they had not been "too young" or inexperienced ("We were both over thirty when we met; we are not kids any more").

Women perceived problem behaviour in the time before pregnancy, but they were more tolerant and ignored it more easily than after the birth, when the intolerance towards male behaviours from female perspective stemmed from fatigue and the need for men to take responsibility for the child and the future. Male irresponsibility began to irritate women. "For him, nothing changed; his lifestyle remained the same, he only thought about himself, leaving me and the child alone, he spent no time with him".

Female participants experienced changes brought by the parental role, and they were bewildered by the lacking male responsiveness to these changes.

\section{Patterns from the family of origin and relationships with parents}

With the childbirth, 'difficult' topics and emotional contents begin to emerge; spouses perceive the patterns from the family of origin as unsuitable; either they change these patterns or the patterns cause problems. "You carry this belief that you must be patient and that a woman isn't allowed to be happy. Only when I allowed myself to think that there are other possibilities and that even if my mother would blame me, I wanted to be satisfied, which I was not, only then I was able to leave", said a participant who perceived her mother's ways of connecting with her father as a significant obstacle preventing her to reach her own happiness. The child's arrival awakens a deeply set pain from the past, and this pain helps making decision to leave a violent relationship. "There were enormous amounts of violence in my childhood. Mother and father fought physically, both of them had alcohol problems; you grow up with this, thinking that's how it is supposed to be. When I gave birth to my daughter something rose up within me; I didn't want her to live in the same hell I did".

Mothers' experience in the first months of the child's life was also influenced by the relationships with their own or husbands' parents, where they got additional support or they were a source of additional stress, especially where boundaries were not consistently and clearly set already in pregnancy. This is indicated by 
the following answers by mothers: "His parents were the problem, always. I was married to them, not to him. He wasn't meant to marry. "When she gave birth, the women imposed themselves over me. My mother-in-law came, she helped, and I couldn't say a word. They didn't want me to be there. I thought this would last one month but she just stayed there. And she is still there; I don't know what to say". From the participants' perspective, parents obviously have great power to influence inappropriate behaviour of their adult offspring. A participant said, "I was very angry with his parents who defended him all along, although I was the victim of his violence. If they had taken my side, he would have changed". His parents took care of everything, yes, they helped, too, but they were around all the time; he didn't have his own opinion, he did nothing by himself. The three of us didn't exist; we were five, all the time". The research showed that with the new-born child, the need to establish appropriate boundaries becomes more pressing. "Before it is not that important; when the baby comes, however, you need to do something, now you invest into next fifty years".

When boundaries are too open, so that there is a fusion of two families, relationships with parents can be the cause of disintegration

The birth of a child - an initiative or an obstacle for making the decision?

The participants perceived the decision for divorce as a responsible move, and the birth of a child as an event which helped them carry out their decision with greater determination. Women said that at birth they became aware of the responsibility of their child, the responsibility to offer the child an environment optimal for his or her development. "He had alcohol problems and I was afraid of physical violence; he had been insulting and irresponsible before. I was very much ashamed. Conflicts started immediately after I gave birth, he was increasingly uninterested and irresponsible as a father. I didn't want my daughter to grow up in such family. I had to protect her".

Women, overwhelmed with plenty of information about the benefits of having both parents and about the consequences of a dissolved family, as well as afraid that their spouse could cause troubles regarding custody/access and would not be a good father, often wondered what could actually be a good solution for the child.

"The feelings of guilt which my partner constantly imposed on me, saying that I was bad mother; the fear that children would suffer because even now he doesn't want to talk and they have no contacts with him". 
"I was afraid that later, my daughter will accuse me because I divorced; that I am the only one to blame because she is without a father".

Men who divorced consensually also highlighted their relationship with the child as a great obstacle when deciding to divorce. "I was aware that she would get custody, this is how it goes, so I stayed in the relationship because of the child, I was powerless and desperate, I noted to her that we need do something, get ourselves help. All in vain".

"Custody was settled by the court and the Social Work Centre. Of course, mother got the custody and as a father I felt really hurt because they didn't listen to me, to my opinion that the child meant everything to me. That's why I procrastinated so long".

The majority of participants were aware that even after eventual divorce, due to their parenthood they would continue to communicate, maintain contacts and establish a level of mutual co-operation. That is the primary reason why they hesitated and only made the decision thoughtfully, not suddenly. The decision is often stressful and difficult. "I was afraid what would happen to the children, because he threatened that he would take them away or call the police if I should take them. I guess I was procrastinating with gathering those papers, and even when I had them all together I needed quite some time to start the procedure".

In some cases, where even before pregnancy, alcohol and infidelity prevailed in a relationship, immediately after the birth of a child the husband became aggressive, too, and decision to leave was made instantaneously, also because the mother feared for her own and her infant's life. "When he hit me I took the child and went to my parents without any baggage whatsoever", a mother said. Another woman, who had tolerated violence for several years, described the moment of breakthrough as follows: "There was one conflict, one flash, when he threatened to kill me. I did not think where I would go. I just took a small bag, basic things for my daughter".

\section{Painful emotions accompanying divorce}

In addition to everyday parenting tasks, life after divorce during the transition to parenthood included adaptation to new environment, the settlement of financial and legal issues with the partner, in some cases also through exhausting procedures at the court, and constant emotional processing of unpleasant emotions which dragged on from the broken relationship to new life. Participants experienced feelings of guilt, shame and disgust because of their bad choices, 
accusing themselves of not having been able to save the relationship, although they had often attempted various forms of professional help; they were afraid how they would live, maintain and establish contacts and relationship with their child. They were thinking of the child's benefit and they were worried how the child would perceive the consequences of divorce and connect with father, or how they would live without constant child's presence.

In some cases they managed to successfully participate in their parental role, while in others the behaviour of ex-spouse continued or escalated: "My ex has remained irresponsible, he doesn't care for the child and has no connection with him. And this hurts". "His aggression has escalated so that he is even officially forbidden to visit his son".

Some female participants turned to professional help but they expressed their desire for more preventive activities in that area.

"You don't know how to solve problems, where to turn for help before it is so late. And you are ashamed and feel powerless". "After divorce you need time, it is hard, really".

"When you are pregnant nobody tells you how tiresome it will be. It is terrifying. Men, too, should hear that priorities will change".

By means of various forms of help and prevention, transition to parenthood can be a pleasant turning point where partners can become even more united and connected instead of facing their pain and dissatisfaction which leads to disintegration of a family even before it formally ends.

\section{Discussion}

The results of the research are in accordance with the findings by international authors $^{29}$ about transition to parenthood as a stressful time period when marriage becomes vulnerable and can undergo a crisis. After the birth of a child, the relationship can grow stronger, it can remain unchanged, or it can take

${ }^{29}$ J. Belsky, The transition to parenthood. How a first child changes marriage, New York 1994, Delacorte Press; P. A. Cowan, C. P. Cowan, When partners become parents: The big life change for couples, New York 1992, Basic Books; B. D. Doss, G. K. Rhoades, S. M. Stanley, H. J. Markman, The effect of the transition to parenthood on relationship quality: An eight-year prospective study, "Journal of Personality and Social Psychology" 96 (2009) 3, p. 601-619; G. Hirschberger, S. Srivastava, P. Marsh, C. P. Cowan, P. A. Cowan, Attachment, marital satisfaction, and divorce during the first fifteen years of parenthood, "Personal Relationships"16 (2009), p. 401-420. 
a distinctively negative course and deteriorate with time, as was the case with the participants in our research.

It has become evident that in the first months after childbirth, women take the majority of household chores and care for the new-born, and that they feel fatigue and loneliness while their spouse is inactive. The new child also awakens several personal vulnerabilities in each of the parents as individuals. Even though the parents both usually feel joy and confirmation with the birth of their child, they at the same time often feel exhaustion, they lack time for themselves, and an imbalance and difference in opinion often arises as how to tend to the new-born and divide family tasks ${ }^{30}$.

The findings of the research have shown that the experiences of marital relationship, transition to parenthood and circumstances which cause the process of decision-making for and actual carrying out divorce, are subjective and individual, intertwined with various risk factors. Some of them are rooted in the past of an individual and of the relationship. The arrival of a child brings forth pain and learned patterns of acting, feeling and thinking, which do not lead to divorce per se; however, they can change during a life stage such as transition to parenthood. For our participants, too, the decision to divorce was related to transformation of these deeply rooted patterns. Psychological structures in relationships with their parents were transformed, too.

We could confirm the findings of a study ${ }^{31}$ about the importance of physical and emotional support from young spouses' parents in the first months after the childbirth; mothers had easier time with the support of their parents or in-laws, but they were also aware of the temporary character of this solution, being dissatisfied with spouse's absence; and over time, in some cases problems in the relationships with their parents emerged, too. That being said, the results draw attention to the need of establishing appropriate relationships with parents, especially when relations across several generations hinder changes in the new family.

${ }^{30}$ P. A. Cowan, C. P. Cowan, When partners become parents: The big life change for couples, New York 1992, Basic Books; J. M. Twenge, W. K. Campbell, C. A. Foster, C. A., Parenthood and marital satisfaction: A metaanalytic review, "Journal of Marriage and Family" 65 (2003) 3, p. 574-583.

${ }^{31}$ J. Belsky, The transition to parenthood. How a first child changes marriage, New York 1994, Delacorte Press; A. C. Glade, A. R. Bean, R. Vira, A prime time for marital/relational intervention: A review of the transition to parenthood literature with treatment recommendations, “The American Journal of Family Therapy" 33 (2005) 4, p. 319-336. 
Young parents are responsible for setting of boundaries with their respective families of origin. When these boundaries are either too permeable or too rigid, relationships with parents cause additional conflicts in the new family, mirroring instability of their marriage and sometimes creating an excuse for dissatisfaction in the spouses' dyad ${ }^{32}$.

The findings of the study show that appropriately set boundaries with families of origin, which include grandparents of the partners, in the new family system, but at the same time do not threaten its autonomy, contribute to strengthening the relationship. Partners are responsible for productive setting of boundaries, where they transcend inappropriate patterns of feeling, thinking, and behaving which developed when they were growing up. If that does not happen, inappropriate triangles can form, and as the research shows, they are an inefficient way of solving difficult situations during new baby's first months. New generational borders are drawn into a family system after the birth, particularly, of a first child. From the perspective of systems theory, this is how new child subsystems are formed, which consequently trigger adaptations throughout the entire family system ${ }^{33}$. Maternal and paternal behaviours, and their new roles in the family system, form gradually in response to external stimuli prompted by the child and the environment.

The findings confirmed that the birth of a new child sheds light on the quality of marriage and the issues from the time before the birth. Participants were aware of problem behaviour, be it violence, alcohol addiction, or other so-called "hard" causes for divorce ${ }^{34}$ as well as the so-called "softer" behaviours prior to the birth of a child, but they ignored/neglected them also due to unreal expectations how their spouse would change after the arrival of the child ${ }^{35}$. Mothers with ideal expectations will be more disappointed after the birth in

32 C. Gostečnik, Sistemske teorije in praksa. [System theory and practice], Ljubljana 2010, Brat Frančišek in Frančiškanski družinski inštitut; N. Rijavec Klobučar, Transformativno učenje $v$ partnerskih odnosih na prehodu $v$ starševstvo [Transformative learning in the transition to parenthood], "Andragoška spoznanja” 17 (2011) 3, p. 31-39.

${ }^{33}$ C. Gostečnik, Sistemske teorije in praksa. [System theory and practice], Ljubljana 2010, Brat Frančišek in Frančiškanski družinski inštitut.

${ }^{34}$ D. Ganc, Izzivi očetovstva po ločitvi. [The challenges of fatherhood after divorce], Sevnica 2015, Družinski inštitut Zaupanje.

${ }^{35}$ N. Biehle, K. D. Mickelson, First-time parents' expectations about the division of childcare and play, "Journal of Family Psychology" 26 (2012) 1, p. 36-45; K. Harwood, N. McLean, K. Durkin, First-time mothers 'expectations of parenthood: What happens when optimistic 
comparison to those with realistic expectations concerning their husbands' share in performing household chores and baby care.

Participants in the research experienced transition from dual to plural in such a way that they saw problems in their marriage differently and could more easily choose divorce as they would have been able to before. When their child is born, adults start to feel more responsibility towards themselves and can make decisions more easily on their child's behalf ${ }^{36}$.

For some participants, the child became an obstacle for their decision to divorce, and triggered reflection about what is optimal for the child's development. Both genders feel the fear concerning a changed family structure and especially custody, but fear was especially prominent in the cases of violence towards women and in worried fathers. According to the latest available data for the year 2010 in Slovenia, only 6,3\% fathers got custody, and 14\% shared custody with the child's mother ${ }^{37}$ research showing that fathers experience deep and extensive emotional changes due to the loss of connection with their child ${ }^{38}$.

One finding of the research shows that childbirth brings a new need for change and taking responsibility when facing vulnerability, within the relationship as well as when the relationship dissolves. Divorcees were aware of their vulnerability when they decided for divorce, as well as of its eventual consequences and difficult emotions they faced both before the decision and after the divorce process was over. Even in cases when the decision was easier because they feared for their child's life, they had to cope with negative feelings of terror, guilt, anger, disgust and powerlessness. Divorce triggers intense and painful feelings which are a natural response to the loss and mark the beginning of a mourning process, having to adapt to a new life situation ${ }^{39}$.

expectations are not matched by later experiences, "Developmental Psychology" 43 (2007) 1, p. 1-12.

${ }^{36}$ N. Rijavec Klobučar, Transformativno učenje v partnerskih odnosih na prehodu $v$ starševstvo [Transformative learning in the transition to parenthood], "Andragoška spoznanja” 17 (2011) 3, p. 31-39.

37 Statistical Office the Republic of Slovenia, Sklenitve in razveze zakonskih zvez, Slovenija, 2014 -končni podatki. [Marriages and divorces, Slovenia, 2014 -final data.] http://www.stat. si/StatWeb/glavnanavigacija/podatki/prikazistaronovico?IdNovice=6303 (23.9.2015).

${ }^{38}$ D. Ganc, Izzivi očetovstva po ločitvi. [The challenges of fatherhood after divorce], Sevnica 2015, Družinski inštitut Zaupanje.

39 B. Simonič, A. Poljanec, Building motherhood in the young mothers' group, "Child Care in Practice" 20 (2014) 3, p. 270-285. 
The need to develop accessible, and available, forms of therapeutic, counselling, and educational help, emerges from research. Such programmes contribute to a more successful adaptation of young couples in their transition to the milestone of parenthood.

The research confirmed that the transition to parenthood represents a life event, or milestone in the couple relationship - one that brings joy and excitement as well as stress and difficulties. This renders the time following the transition to parenthood as critical, and learning to properly approach and deal with the challenges that arise is determinative of whether the relationship will develop into a healthy and vital one, or whether it will deteriorate ${ }^{40}$.

\section{Implication}

The findings of the study are similar to existing findings about divorce as a stressful experience ${ }^{41}$ they do, however, help understand the aspect of coping with divorce during transition to parenthood, when the beginning of a new life is almost simultaneous with leaving one part of old life behind.

The results of the research contribute to the development of education programmes for future parents. Such programmes are extremely rare in Slovenia. Trainings for future parents are held in health-care institutions, but they mainly focus on child care topics, excluding relational contents which proved efficient in programmes abroad. Some non-governmental organizations do offer various support groups for parents and new mothers ${ }^{42}$, but it would be highly necessary to develop these groups, perhaps through forms of education which people perceive as safe and familiar. The results are also intended for professionals who provide consulting, psychotherapeutic, educational, and legal support to divorced adults.

${ }^{40}$ G. Hirschberger, S. Srivastava, P. Marsh, C. P. Cowan, P. A. Cowan, Attachment, marital satisfaction, and divorce during the first fifteen years of parenthood, "Personal Relationships" 16 (2009), p. 401-420.

${ }^{41}$ P. Amato, Research on divorce: Continuing trends and new developments, "Journal of Marriage and Family" 72 (2000) 3, p. 650-666.

${ }^{42}$ B. Simonič, A. Poljanec, Building motherhood in the young mothers' group, "Child Care in Practice" 20 (2014) 3, p. 270-285. 


\section{Limitation and future research}

It should be emphasized that the results are only valid for this research. Transition to parenthood is an individual experience; spouses have different perspectives on transition to parenthood as a risk factor for divorce. Speaking of limitations, we want to question the results we would get if a) participants would be divorcees who had been left behind, or b) research would be conducted by means of different methodology and, perhaps, other institutions (e.g. Social Work Centre), or c) it would be conducted in another time period or with both ex-spouses. Another limitation is also the fact that people voluntarily shared this personal experience, and some of them felt an urgent need to talk about their pain. Suggestions for further research include expanding research to a wider population and the use of additional research devices with the expansion of research interest which would also encompass other factors.

\section{Acknowledgments}

"The authors acknowledge the financial support from the Slovenian Research Agency (project No. J5-6825)”.

\section{Bibliography}

Belsky, J. The transition to parenthood. How a first child changes marriage, New York, Delacorte Press 1994.

Clarke-Stewart, A., Brentano, C. Divorce: Causes and consequences, New Haven CT, Yale University Press 2006.

Cowan P. A., Cowan, C. A, When partners become parents: The big life change for couples, New York, Basic Books 2000.

Feeney J. A., Hohaus L., Noller P., .Alexander R. P., Becoming parents: Exploring the bonds between mothers, fathers and their infants, New York, Cambridge University Press 2001.

Nazarinia Roy R., Schumm W. R., Britt, S. L., Transition to parenthood, New York, NY, Springer Science + Business Media 2014 .

Nilsen A., Brannen J., Lewis S., Transitions to parenthood in Europe: A comparative life course perspective, Univesity of Bristol, Policy Press 2012.

Wolfinger, N., Understanding the divorce cycle: The children of divorce in their own marriages, New York, Cambridge University 2005. 